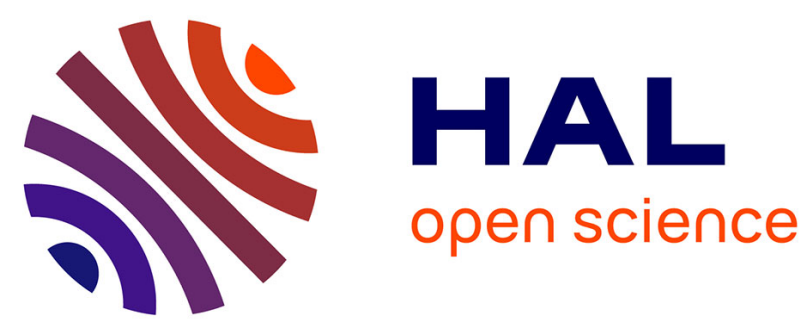

\title{
EFFECTS OF FINANCIALIZATION ON RESTRUCTURING AND SUSTAINABLE DEVELOPMENT POLICY: THE ACCOR GROUP CASE 1
}

Jocelyne Barreau, Juliette Arnal

\section{To cite this version:}

Jocelyne Barreau, Juliette Arnal. EFFECTS OF FINANCIALIZATION ON RESTRUCTURING AND SUSTAINABLE DEVELOPMENT POLICY: THE ACCOR GROUP CASE 1. Sun, W., Louche, C. and Pérez, R. Finance and Sustainability: Towards a New Paradigm? A Post-Crisis Agenda, 2, Emerald Book, pp.249-272, 2011, Critical Studies on Corporate Responsibility, Governance and Sustainability, 978-1-78052-092-6. 10.1108/S2043-9059(2011)0000002023 . hal-02381956

\section{HAL Id: hal-02381956 \\ https://hal.univ-rennes2.fr/hal-02381956}

Submitted on 26 Nov 2019

HAL is a multi-disciplinary open access archive for the deposit and dissemination of scientific research documents, whether they are published or not. The documents may come from teaching and research institutions in France or abroad, or from public or private research centers.
L'archive ouverte pluridisciplinaire HAL, est destinée au dépôt et à la diffusion de documents scientifiques de niveau recherche, publiés ou non, émanant des établissements d'enseignement et de recherche français ou étrangers, des laboratoires publics ou privés. 


\title{
EFFECTS OF FINANCIALIZATION ON RESTRUCTURING AND SUSTAINABLE DEVELOPMENT POLICY: THE ACCOR GROUP CASE ${ }^{1}$
}

\author{
Jocelyne Barreau and Juliette Arnal
}

Avant-dernière version du texte paru dans William Sun, Céline Louche Roland Pérez (éd.), Finance and Sustainability: Towards a New Paradigm? A Post-Crisis Agenda, Critical Studies on Corporate responsibility, Governance and Sustainability, Volume 2, 249-272, Emerald Books, 2011

Restructuring is part of business life and is necessary for a firm's survival and development. It manifests itself in various ways.

\begin{abstract}
"Restructuring is a complex multifaceted and multidimensional process that includes changes in the organization of the company, in its form, scope and activities. It is the result of multiple economic purposes and objectives of the company management according to changes implied by the globalization of the economy. It manifests itself through the closing of businesses, increased flexibility, streamlining of the business, national as well as international outsourcing and structural and functional expansion and diversification having major consequences on the structure and quality of employment" (Moreau, Negrelli, \& Pochet, 2009, p. 15).
\end{abstract}

All major companies experience restructurings. In addition, most large multinational firms now claim to have a sustainable development policy. Contemporary companies are expected to get involved in a socially responsible process. A sustainable development policy, called a ' $\mathrm{CSR}^{1}$ policy', in business communication and in literature, gives the company responsibility towards the various 'stakeholders' involved or affected by its activities. 'At least the point is to internalize the externalities and ideally to increase collective welfare' (Noël, 2007, p. 302). This logic implies that the firm will minimize any negative impact on the environment, will choose a social policy that is focused on its employees (personal development, skills management), will offer quality goods or services to its customers at reasonable prices and will pay dividends to its shareholders. Other stakeholders are of course involved (unions, suppliers, subcontractors, local residents near the company sites, local authorities ...).

However, the term 'restructuring' often has a pejorative connotation, being associated with job cuts and layoffs. During a restructuring, 'managers' duties from the contracts that bind parties' are more or less taken into account (Noël, 2007, p. 303), yet it is the will of the shareholders that are often preferred. On the other hand, responsibility to the employees may be overlooked because employer assignments are, often, not so much stated in employment contract but are built throughout the social exchange that is the employment relationship, and have implicit and psychological aspects (Noël, 2007, p. 307). It is the consistency of restructuring and the respect of sustainable development policies, especially of social commitments, that is at issue.

Fayolle (2006, p. 22) states that 'responsible treatment of restructuring and relocations must be an indispensable point in both the content and the exercise of CSR in countries confronted with the constraints of acute competition'. The $\mathrm{EMF}^{2}$, a very active European Union federation, laid down 10 guidelines to make certain a transnational restructuring would be 'socially responsible' (Béthoux, 2008, p. 101). For Ray (2006), a 'socially responsible'

\footnotetext{
${ }^{1}$ This research was conducted in the ANR financed program 'CSR Regulation Potential'.
} 
restructuring means to anticipate and ensure employees' employability. However, the author also states that anticipation is very difficult in the 2000s as restructuring is a quasi-permanent activity and company boundaries continuously alter. The best protection a multinational enterprise (MNE) could offer its employees is through training and occupational development.

If it can be admitted that a 'socially responsible' restructuring is possible, what happens when a company is financialized, that is when an investment fund becomes a major shareholder? Group financialization is seen as the prelude to restructuring, job cuts, layoffs and detrimental managerial methods (Allouche \& Garaudel, 2007; Lazonick \& O'Sullivan, 2000). Can this restructuring be socially responsible? Can a multinational firm bring investment funds into its share capital while still respecting its sustainable development policies, including its social commitments?

At first glance, using the example of Accor Group, the answer is yes. Accor communicates consistently and often about its sustainable development policy and uses cutting-edge social instruments to achieve this. It controls its franchises (charter, audit) and its subcontractors (collective agreement). It has been permanently and profoundly restructured since a U.S. investment fund entered its share capital in 2005, without neither a significant reduction in its global workforce nor layoffs (2005-2009 reference reports). In studying the details of the Accor Group case, the consistency of share capital financialization and top management's respect for its social commitments ${ }^{3}$ is examined. This is an important issue as financialization is an established and growing phenomenon. What lessons can be learned from the Accor example?

The conceptual framework and the methodology of the study is first presented. Then, the Accor Group case is analysed along three lines: (i) the social and environmental policies continually claimed by Accor top management, (ii) the financialization, that is the change in shareholding and the strategic shifts in 2005 and 2009 and (iii) its restructurings and their consequences on the group's employees. Finally, results and conclusions are presented.

\section{CONCEPTUAL FRAMEWORK AND METHODOLOGY}

Our objective is to test the consistency between share capital financialization, implementation of responsible restructuring and sustainable development policy, focusing more particularly on the implementation of corporate social commitments. In order to develop a model that puts these three processes (restructuring, financialization and social policy) in perspective, we proceed in two steps: we examine the consequences of financialization on both the restructurings and on HRM practices and then the consequences of restructurings due to financialization on employment, the evolution of labour management and the functioning of HRM as seen in management literature. The methodology used to test this model on the Accor Group case is presented.

\section{Financialization and Restructuring}

How does 'new governance' (characterized by Anglo-Saxon institutional investors in a firm's share capital) influence restructuring decisions? U.S. institutional investors are seeking a high return on capital, in the form of distributed (possibly special) dividends and stock market gains, which are obtained when selling shares in their possession. They advocate strategic choices that are focused on 'a dual principle of specialization and fluidity/flexibility of 
organizational forms: heart of business focusing, outsourcing, network organization reengineering, downsizing' (Allouche \& Garaudel, 2007, p. 33). These strategic shifts explain why U.S. firms that had a 'retain and reinvest' strategy in 1960s and 1970s, adopted a new 'downsize and distribute' strategy during the 1990s (Lazonick \& O'Sullivan, 2000).

It also explains the restructuring operations over the last 20 years. In this new governance model, which gives a major role to investment funds, the influence of financial markets has significantly increased, and incentives and constraints of market valuing for the company and the managers are intensified.

Managerial decisions, particularly restructuring decisions may come, in some cases, from the choice to guide market perceptions and expectations and to act, at least in the short and medium term, on market value process [...]. Strategic and organizational decisions are themselves signals to the financial sphere. Thus, firms business choices are linked to their corporate communication policy towards investors, which can have adverse effects on the economic rationality of the decisions taken. (Allouche \& Garaudel, 2007, pp. 44-45)

French companies' financialization ${ }^{4}$ would clearly have a direct impact on their restructuring decisions and these decisions would probably come into conflict with a social policy focused on employees' personal development as they are likely to lead to layoffs. But what does one know about the links between this new governance model and human resources management (HRM) practices, between these new restructuring logics, labour management and HRM evolution?

\section{Financialization and HRM}

Montagne and Sauviat (2001) partly answer the first question regarding the links between the new governance model and HRM. On the basis of nondirective interviews with the principal actors in the U.S. pension funds industry, French consulting firm leaders, directors of large French companies as well as their employee representatives, they show that U.S. investment funds have a normalizing effect on labour management practices. They find segregation between a handful of executives judged as essential to the creation of stock market value, executives and managers of profit centres, and the remainder of the workforce. These managers profit from individualized career plans and are the main beneficiaries of financial incentive methods. Other employees are locally managed.

A quite different study was conducted by Conway et al. (2008). On the basis of the WERS British survey (Workplace Employment Relations Survey) and the REPONSE French survey (Relations Professionnelles et Négociations d'Entreprise), the authors analysed how stock exchange listing influences HRM. The statistical analysis, comparing HRM practices in firms listed on the stock market to those of unlisted companies (e.g. mutual insurance companies and sales/production cooperatives), gave the following results: British and French establishments belonging to listed companies have strong incentive HRM practices based on teamwork and performance pay (individual and collective). In addition to these characteristics, the French establishments also have management practices that focus on employee autonomy and continuing education. On the other hand, in no case are the employees involved in change management nor do they contribute to setting local goals. However, these results are global. This analysis does not take into account the companies ownership structure and does not distinguish companies in which Anglo-Saxon financial investors have a large influence on strategic decisions from other companies (with a more classical ownership structure). 
So it is clear that financialization has an impact on HRM practices. It favours HRM practices that create a separation between top managers and workers, strong incentive programs and a decentralized HRM.

\section{Restructuring, Labour Management and HRM Evolution}

Pichault and Rorive (2007, pp. 200-201) distinguish three types of restructuring depending on their purpose and with differing effects on employment. Digital restructuring aims at downsizing, using all mean possible including layoffs. Functional restructuring is based on 'business process reengineering' and implies employees' layoffs due to a productivity change. Strategic restructuring 'leads to a new business process which not only changes the organizational scope but also unlinks it from the firm's legal boundaries'. This last form of restructuring, 'without a doubt the most recent', and today the most common, generally operates with outsourcing, giving birth to a business network. It leads to a 'restructuring of labour force (availability, transfer, skill pooling etc.)'. It is accompanied by gentler measures of employee reductions but 'it seems to present major challenges to the evolution of human resources management'. The authors distinguish three network configurations having various impacts on HRM.

In the pendulum network, 'workers within a legal framework are integrated into the organizational framework of other legal entities' (ibid., p. 203). 'The integrated network is characterized by a single organizational framework that includes several legal frameworks' (ibid., p. 202). It is the result of externalizing the employee relationship (outsourcing). The federated network 'consists of a central, often very large, enterprise grouping in a permanent or long term relationship, smaller, sub-contractor firms for a part of the business. This kind of network is characterized by a split between the legal and organizational frameworks and by the recomposition of a single organizational framework around the partnership activity' (ibid., p. 203).

The analysis of business network cases corresponding to these three different configurations allowed the authors to characterize their HRM practices. In the integrated network, a clear segmentation is in operation between the "personnel in key positions to increase value for the firm' and the workers (ibid., p. 205). For the first group, HRM is involved in personal development and skill management. The second group is under local administration (ibid., p. 208). In the pendulum network, this simple administration of personnel based on the control of employee costs affects the ensemble of personnel and is a type of management particularly difficult for personnel. In an integrated network, the evolution of the management of human resources is directed towards a media approach. 'The end customers have become the principle interlocutors in this media positioning: the goal is to create the impression of a community - granted a virtual one - delivering goods and services as if it was operating as a unique entity' (ibid., p. 210). HR is equally responsible for 'the visibility of the Group's global social responsibility, most often with the goal of improving its external image' (called social marketing) (ibid., p. 211).

So strategic restructuring, giving rise to business networks, affects work management practices and the role of HRM, in various ways.

To summarize: In companies with classical ownership structure, the consistency between 'functional restructuring' (Pichault \& Rorive, 2007) and sustainable development policy (especially social commitments) is possible. A 'socially responsible' restructuring would 
mean anticipation of restructuring and employee employability based on training and occupational development (Ray, 2006). In 'financialized' companies, the effects of financialization are diverse (figure 1).

To test this model on Accor Group case, it is necessary to demonstrate that (i) despite the claimed corporate sustainable development policy, Accor restructuring is not 'socially responsible' because employees representatives are provided with neither anticipation of restructuring nor employee employability programs, (ii) Accor financialization, important strategic and earnings distribution changes had occurred in 2005, (iii) Accor restructurings have been 'strategic' and have given birth to either a pendulum or integrated or federated network organization and (iv) have generated job cuts, HRM decentralization and segmentation, elementary or media-oriented HRM practices.

Fig. 1. Effects of Financialization on Restructuring, HRM Practices, Distribution of Earnings and Social Policies.

\section{Methodology}

To test this model, the case study method that is an empirical research method was chosen. It has a 'clear advantage' when 'questions of how and why are asked regarding a set of contemporary events, on which the researcher has little or no control' (Yin, 2009, p. 13). This empirical research meets the three conditions set by Yin $(2009$, p. 8) arguing for the use of this method as a way to 'understand a complex phenomenon'.

_ Our research questions reflect the 'how' and 'why'. How can Accor's claimed and effected policies (environmental and social ones) and strategic choices be characterized? Why did the strategic shifts in 2005 and 2009 occur? Why is there an apparent incoherence between the claimed policies of sustainable development and the strategies put in place? Why does restructuring not produce the expected effects on employment? Are these strategic decisions deliberate management choices put into effect to achieve a hidden goal or are they the result of strong external constraints?

_ As researchers, we have no control over 'behavioural events'. In other words, we cannot manipulate actors' behaviours, which would be the case in an experimental method.

_ The analysis is focused on recent facts and thus it is possible to observe and interview key actors (which gives a clear advantage to the case study method compared to an historical approach).

Finally, the choice of the Accor case seems discerning in that the company has displayed a proactive sustainable development policy since the end of the $1980 \mathrm{~s}$ with continual restructuring. In 2005, the U.S. investment fund, Colony Capital, became an Accor major shareholder (2004 reference report, p. 26).

The Accor Group has 150,525 employees, according to reports by the management team in 2009 and is located in 140 countries. In 2009, it became the first European group, and one of the first worldwide groups, in the hotel business $(4,000$ hotels in 90 countries, casinos, travel agencies and restaurants) as well as world leader in the prepaid services to businesses and public institutions (restaurant vouchers, food services and personal assistance). This second business employs 6,100 people (for 139,700 in the hotel business) and covers 32 million users (2009 reference report, pp. 4-29). 
Based on the Accor case, the analyses can be generalized as the three discussed processes (restructuring, financialization and sustainable development policy) coexist in most of the major international groups.

Data collection was conducted within the framework of the research program 'CSR Regulation Potential'. We analysed CSR policies, strategic shifts and transnational collective bargaining development of four French companies (Accor, Danone, France Télécom and EDF) during the last 25 years.

The study was conducted on the basis of documentary sources (academic and expert studies), semi-directive interviews and documents provided by our interviewees (MNE top management, trade union employee representatives, Global Union Federations, European Union Federations, National Sectoral Union Federation officials). These documents, produced by Accor Group management (reference reports from 1997 to 2009, annual reports from 2004 to 2009, 2009 institutional brochure and Group press releases) also included agendas, lists of the participating members and reports drafted by Accor's European Works Council (EWC) secretary since its creation, signed agreements texts, agreements and common statement drafts.

Using guidelines, the interviews were carried out in 2008, 2009 and 2010. They lasted from 45 minutes to $2 \frac{1}{2} 2$ hours. The collected information was transcribed and analysed on the basis of the interview guideline structure.

For Accor, the following people were interviewed: an HR manager (January 2009), trade unionists including 10 French Union Federation representatives and 6 French EWC members, a foreign EWC member (2008, 2009 and 2010), 2 European Union Federation representatives (November and December 2009), a European Trade Union Confederation (ETUC) representative (November 2009), an International Union of Food (IUF) ${ }^{5}$ official (January and September 2009) and the expert chosen by the unions to analyse the information provided to the EWC (March 2010).

As observers only, the researchers attended ETUC meetings and Accor preparatory and follow-up EWC meetings (October 2008) ${ }^{6}$.

\section{CLAIMED SOCIAL AND ENVIRONMENTAL POLICIES}

Among hotel groups, Accor is a sort of pioneer due to its environmental and social initiatives. The tourism industry is particularly concerned by environmental sustainability as it only exists due to its environment attractiveness (Caire, 2004). Social issues (balancing of mass tourism and sustainable tourism, child labour issues), economics (issues related to the local economy) and environmental issues (management of environmental impact related to tourism and climate change) render tourism activity vulnerable both in developing and industrialized countries (Wahab \& Pigram, 2007). Despite the challenges inherent to the industry and despite the Tourism Ethics Code adopted by the World Tourism Organization in 1999 (WTO, 2005), firms of this sector have delayed getting involved in sustainable development issues. In this context, Accor is considered to be exemplary, in particular by non-financial rating agencies.

Moreover, Accor's social policy is characterized by the use of cutting-edge instruments: a European employee information and consultation committee in 1994 (and then an EWC), a 
signed International Framework Agreement (IFA) on trade union rights in 1995 and signed national collective agreements, on sub-contracting (in 2002), on diversity (in 2007) and a franchise charter (in 2007).

\section{The European Employee Information and Consultation Committee (1994)}

After two years of negotiations between Accor HRM, French trade union representatives and those of the IUF, the Accor Group's 'European Committee for Social Dialogue' was created in 1994. Following these negotiations, the IUF, the five French representative trade unions and the Accor president signed an agreement establishing the Accor EWC in 1996. This agreement was negotiated fairly quickly, as it took points from the 'European Committee for Social Dialogue' discussions set up two years earlier (Barreau \& Arnal, 2010).

An EWC creation was often a way to assert CSR management commitment (Béthoux, 2008). The Accor Group's top management anticipated the legal obligations linked to the 94/45/CE 22 September 1994 European directive ${ }^{7}$ and agreed to negotiate with a global union federation (IUF). The agreement states that Accor EWC members are composed of 19 employees having a staff representation mandate, named by the IUF, and 5 representatives of trade unions. Management's social commitment is quoted in the EWC agreement: its mission is the 'promoting of social development and labour management dialogue'.

\section{An International Framework Agreement (IFA) on Trade Union Rights (1995)}

As soon as the European Committee for Social Dialogue took place in 1994, the IUF representative (president of this committee) proposed the signing of an IFA on trade union rights to the group's management. With the agreement signed in 1995, the Accor Group became one of the first signatories of an IFA ${ }^{8}$. The agreement quotes the 87, 98 and 135 International Labor Organization (ILO) core conventions regarding freedom of association and trade union discrimination. This agreement, guaranteeing the implementation of these conventions in all Accor Group establishments, underlines employees' right to join a trade union of their choice and includes employees'protection against any discrimination act that can restrain trade union freedom.

\section{Signing of National Collective Agreements}

In 2002, French subcontractor employees, working as cleaning operatives in Accor Group hotel rooms, went on strike. Accor top management initiated a negotiation with the unions represented in the parent company. These negotiations end in the signing of an agreement ${ }^{9}$ which established principles governing providers' employment conditions and contractual conditions between a French Accor hotel and an external cleaning firm. These measures were expected to diminish subcontracting for room cleaning. The agreement, signed in 2002, specifies work hours, the calculation of hours worked, as well of the obligation to provide training for employees of external agencies. It provides for consultation with competent works councils in case of 'any and all modifications having to do with cleaning' and also created a joint monitoring commission (French trade unionists, interviews of November 2008, January and March 2009).

The Group's commitment to diversity became real in 2004, with the signing of the 'Diversity in Business Charter'. In 2006, negotiations on diversity were opened with the French unions within the group and which ended with the signing of a national agreement with all French unions in January 2007. The agreement aims to ensure non-discrimination and equal 
treatment. It covers direct and indirect discrimination, whether conscious or unconscious, concerning real or supposed origin, sex and age. It also covers equal access to employment, to the evolution and advancement of this employment throughout employees' professional life in the company, whether as regards recruitment, training, remuneration or career. A follow-up of the agreement will be carried out by opinion polls and a consulting committee (the Social Council) will ensure its implementation.

\section{The Adoption of a Franchise Charter (2007)}

The Accor Group set up a franchise charter in 2007 in order to bear witness to the groups' will and commitment to implement a more balanced partnership between franchisor and franchisees: 'This Charter is a joint statement which commits each party to respect profession fundamentals. It is also, for all, an insurance of a more empowering and more professional daily relationship' (2007 annual report, p. 33). Quality requirements are strictly defined. A point is also dedicated to protection of the planet and the environment, but no social provisions are included in the document. The Group explains this void by using the autonomy of franchised hotel management as a reason not to include this in the charter, despite repeated requests of staff representatives in various forums, including the Accor EWC (French trade unionists, interviews of November 2008, January and March 2009, IUF official, interview of September 2009).

\section{SHAREHOLDING FINANCIALIZATION AND STRATEGIC SHIFTS OF THE 2000s}

In 2005, a significant ownership change occurred. Strategic shifts occurred as well in 2005 and 2009.

\section{Ownership and Managerial Changes}

In 1981, after successive acquisitions, the group reached a significant size in the sector and was introduced on stock exchange. Novotel-SIEH-Jacques Borel International Group, a large and significant hotel group present in catering and public or business services, became Accor in 1983. In 1997, 'the group chooses a new management structure: the two founders have become supervisory board co-chairmen with Jean-Marc Espalioux being nominated Executive Chairman' (1999 reference report, p. 4).

In 2005, the U.S. investment fund, Colony Capital, 'is investing one billion euros in Accor, in bonds redeemable in shares and in convertible bonds of 500 million euros each' (2006 reference report, p. 13). In 2008, Eurazeo, a French investment firm, and Colony Capital enter into a five year shareholder agreement on investment in Accor (Eurazeo website, 6 January 2010). Eurazeo has $10 \%$ of Accor share capital. In 2009, the two groups have $30 \%$ of Accor share capital (according to $\mathrm{AMF}^{10}$ statements, 9 February 2009).

These changes in the ownership structure caused a governance change and departure of the former management team. A board of directors replaces the management board and supervisory board in 2006. The composition of the Group's board of directors reflects the growing influence of financial investors. At its creation, in January 2006, 2 representatives of Colony Capital (including the founding CEO) joined the Accor board of directors, composed of 17 directors. In August 2008, the Eurazeo chief executive entered into, what is now, a 15member board. By May 2009, the Accor Group Board is reduced to 12 members, with Eurazeo including a second representative (Accor press release of 13 May 2009). Out of the 12 members of the Accor Board, 4 represent the Colony and Eurazeo interests and can play a 
major role (as will most probably be the case for voting for a group split up into two separate companies at the meeting of 19 December 2009).

\section{Strategic Shifts in 2005 and 2009}

The 2005 shareholder change had a significant impact on the Accor Group strategy. 'The Colony Capital 1 billion investment and involvement in an innovative real estate policy will give us leeway, strengthen our financial structure and significantly accelerate our development' (2004 reference report, p. 24).

The new real estate approach shows a clear strategic shift as it involves outsourcing the group real estate in an 'innovative way' that is to say, to adapt 'hotel operating to market segments depending on employed asset profitability and the volatility of their results [y]. In this context, an assets review determines priority hotels with long run operating, and non-priority hotels may be sold with or without a franchise agreement' (2005 reference report, p. 16). Real estate outsourcing is broken down as follows: 'Accor sells high level hotel real estate in order to retain long term hotel management contracts, possibly with a minority stake in the owner company; in mid-range hotels, Accor is trying to convert fix rental contracts with purchase options in variable rental contracts, with a proportional sales rent' (ibid., p. 16). The group development policy is redefined: it will be based 'on market growth potential' (ibid., p. 16). To this end, 'Accor will invest 2,500 million euros for 2010 with a target of $15 \%$ return on capital' $^{11}$ (ibid., p. 17). In the Group's 'services activity', the strategic shift is less obvious since the strategy of increasing market share through external growth operations is still in place. The only significant change compared to the previously outlined strategy is the particularly high goals for return on capital employed (ROCE). 'Accor will invest 500 million euros in this business until 2010, with an expected 20\% return on capital" ${ }^{2}$, (ibid., p. 17).

To highlight this strategic change, remember that in the late 1990s, the group was satisfied with its capitalistic hotel operations approach: 'Accor is the only group worldwide to own and manage, for its own account, more than two-thirds of its hotels' (1997 reference report). In fact, this new policy points to a modification of the heart of the Group's business. 'Accor is becoming more of a hotel operator that sells its expertise and acquired know-how. This is also a cultural change for the group that is becoming, above all, a high value-added provider' (2007 annual report, p. 63).

The business structure of the hotel group (measured in percentage of number of rooms) has changed in 10 years (1998-2008): ownership has gone from $33 \%$ to $22 \%$, contract management $19 \%$ to $22 \%$, franchise $12 \%$ to $19 \%$, variable rental $0 \%$ to $15 \%$ and fixed rent $36 \%$ to $22 \%$ (1998 reference report, p. 7; 2008 reference report, p. 9). The ROCE is $14.1 \%$ in 2008. In the same year, the hotel's business ROCE is $12.9 \%$ and service ROCE is $23.3 \%$ (2008 reference report, p. 60). This is a clear and significant evolution, as from 1996 to 2005 the Group's ROCE never goes above $10 \%$, with a clear difference between hotel operations and services.

In August 2009, the management group announced a possible split of activities (hotels and prepaid services) into two separate companies (Le Monde, 16 December 2009). Financial newspapers underline that the Colony-Eurazeo pact advocates this solution. The FSI (which stands for French Caisse des Dépôts et Consignations-the Deposit and Consignment Office), a 7.5\% capital shareholder, considers that this puts the Group's future in danger (interview of 
FMI director in Le Figaro, 11 December 2009). The board of directors approved the transaction in December 2009.

\section{RESTRUCTURINGS AND THEIR IMPACT ON EMPLOYEES}

The Accor Group is involved in major restructuring operations (purchases and sales of companies in its two activity areas). At the same time, it is leading operations that are more discrete, such as concluding franchise and management contracts and selling hotel buildings, transactions that are not without consequence on employment and employee working conditions. The profound social repercussions from restructurings (i.e. major changes in manpower size and structure, social benefits called into question) would appear to be hidden.

\section{Heteroclite Restructuring Processes}

Initially coming from a company owning one hotel in 1967, Accor has become a major global group in the hotel industry business based on its external growth operations. The Group's history is both founded on hotel acquisitions and, after the Jacques Borel International ${ }^{13}$ purchase in 1982, on service activities acquisitions. Some transactions are only financial holdings, depending on market opportunities. The group sells companies, in part or in whole, when their profitability goes down or when the transaction is financially attractive (capital gains). While restructuring transactions (buying and selling) occupy an important place in each of the Group's reference reports, the strategic reorientation of 2005 is clearly demonstrated in the Group's operations.

Certainly, from 1997 on, Accor's reference reports mention the objectives of improving profit and value for its shareholders as well as the necessity to improve the ROCE. However, beginning in 2005 , these operations took on a very different scale as the objectives fixed by the shareholders for ROCE were very high: $15 \%$ in hotel business and $20 \%$ in services (2005 reference report, p. 17). While the Group's strategy presentations all begin with 'The group is anchored in two global businesses: hotels and services' (2005 reference report, p. 15), for the first time it is said that the 'partnerships strategy with leading global real estate actors' (2005 reference report, p. 16) is essential for a group that plans to sell its real estate assets (i.e. hotels) as quickly as possible. The 2008 reference report lists sales: 'From 2005 to 2008, 625 hotels were restructured ${ }^{14}$ [...]. The group has accrued 4,082 million euros from asset management strategy ${ }^{15}$, on 625 hotels' (2008 reference report, pp. 21-22).

One can note the choice of vocabulary used: 'restructured hotels' means sale of hotel property and/or operating shift; which correspond to Accor's 'asset right strategy'. 'Focusing on the two activities' is used for the first time in 2006 (2006 reference report, p. 15) to justify the extent of asset sales. And yet, the policy of development was not interrupted. The group continues to make acquisitions, mainly in services, and this activity is presented as a sign of the Group's dynamism (eight acquisitions in 2007 and 2008). In the hotel business, Accor pursues its expansion, as measured by the number of rooms: 28,000 rooms opened in 2008 and an objective of 40,000 in 2010 (2009 institutional brochure, p. 2). These rooms are opened essentially in hotels not owned by the group.

The method of management clearly preferred by Accor is the management contract. Accor sells 'real estate and hotel operating in order to keep a long term management contract with possibly minority shares (about 25\%) in the share capital of the company that owns the hotel' (2005 reference report, p. 16). It is also possible to sign such a contract with the company that will build and run the hotel under Accor management team control. Hotel management 
evolution (2008 reference report, p. 156) shows that in 2012 (and in the following years), 85\% of new rooms will be under contract management.

\section{Major Changes in Workforce Size and Structure}

The management contract is a very specific method of management. It differs from franchise contract on one point: the management contract hotel is managed by a management team composed of one $^{16}$, or more, Accor managers. Other hotel employees are not Accor employees. As page 33 in the 2007 annual report says: 'management contracts have an influence on teams' daily lives. They use Accor know-how, but they are now under the authority of the investors who own the hotel'. Hotel sales, franchise and management contracts lead to significant outsourcing of jobs and activities.

According to reference reports from 1997 to 2009, the Group's workforce increased from year to year except in 2008 and 2009. In 2009, Accor had 150,525 people working in group brands, compared to 158,162 in 2008, 172,695 in 2007, 170,417 in 2006 and 168,623 in 2005. What can explain this overall workforce increase (until 2007) despite significant changes in hotel holdings? Remember that the on-going acquisition policy was not able to compensate for the reduction in workforce. The buying policy had been mainly focused on the services business since 2005 and this activity had only 6,100 employees in 2009.

The way the workforce was counted and presented in reference and annual reports masked these cuts. Beginning in 2006, to count the Accor workforce, reference and annual reports refer to 'the group's scope of influence', that includes the following:

_ employees, full time or part time, with a permanent contract, a fixed term contract of more than three months or a learning contract;

_ in subsidiaries and units under Accor management contracts, $100 \%$ of the workforce size is taken into account, but units in which Accor holds a stake but has no liability in, management teams are excluded (2006 reference report, p. 26).

This method of accounting for the workforce is questionable. Employees on temporary contracts and learning contracts are included in the workforce as well as employees on permanent contracts. The part-time employees are not counted on the basis of their worked hours, that is an employee who only works a few hours a week is counted the same as a fulltime employee. Management contract hotel employees are considered as group employees while they are actually employees of the hotel owner. Finally, subsidiary employees are all counted regardless of Accor shares in subsidiary stock capital. Workforce was not counted this way prior to 2006. The 2004 and 2005 reference reports say that 'in the subsidiaries that are $50 \%$ owned by Accor, only 50\% of the workforce is counted'. This indicator disappeared from 2006 in group reports.

A change also appeared in the employee skill qualification structure. Since 2005, reference reports provide details on manager proportion in the workforce. It is 13\% for 2005 and 2006, $14 \%$ for $2007,17 \%$ for 2008 and $16 \%$ for 2009 . This change in the executive proportion in the workforce shows a gradual cut in the low skilled jobs that have, in fact, been given to external firms.

\section{Social Benefits: An Unspoken Challenge}

The group's management claims that social dialogue is the basis of its human resources policy: 'Accor is committed to a constructive social dialogue with social partners and thus 
committed to preserving a quality social environment' (2008 reference report, p. 36). Yet EWC members' dissatisfaction should be brought to light. They feel they cannot properly undertake their role as employees' representatives and constantly remind top management of the need to promote the international 1995 trade unions' rights agreement, which is neither really known in French hotels nor abroad (Barreau \& Arnal, 2010).

The existence of this agreement enabled unions to be accepted in a few hotels in North America, after their employees engaged in hard social actions and the IUF asked the Group's top management to push local management to enforce the 1995 agreement (Wills, 2002). The group's management team refuses to revise the agreement towards a more comprehensive understanding of trade union rights (Barreau \& Arnal, 2010). Some interviewees believe that the management would rather go back on some of the social benefits obtained in the 1990s, such as trade union representation in the EWC. They add that the current top management team would probably not sign the agreement on trade union rights, if it had to do so now (French trade unionists, interviews of November 2008 and January 2009, IUF official, interview of September 2009).

The social policy conducted since the change in top management in 2006 has led to a sort of unspoken questioning of the acquired social benefits. Many agreements signed only apply in France as they were either not negotiated on a European or global level or have just not been signed in other countries. The EWC representatives have asked for geographical extension of these French agreements. According to the trade union representatives, these agreements signed with the unions and which have been part of the Group's corporate communication policy since 2002 are, in fact, only decoration for which Accor 'wins trophies' and which remain difficult to implement Council (French trade unionists, interviews of November 2008 and January 2009, IUF official, interview of September 2009).

According to unions' representatives, the commitments made in 2002, at the time of subcontract agreement, have not been fulfilled. What is more, the agreement is only implemented in France and in a decreasing number of hotels as the hotels change hands. Franchise and management contracts outsourced jobs. These worries are clearly communicated in the statement made by the EWC members during a special meeting (14 January 2010) dedicated to the separation of the two Accor activities: 'the European committee believes that the Group, directly managing less and less assets will employ less personnel directly. This trend is indicative of social regression: degradation of work conditions, impact on salary...' (IUF internal document, 2010).

\section{DISCUSSION}

As we have seen, the Accor Group is an exemplary case illustrating the upsets brought about by the financialization of an enterprise. These changes, affecting all levels (strategic orientations, investment, social and communication policies...), completely correspond with the model (see Fig. 1) that has been elaborated on the basis of the academic literature.

\section{Financialization and Distribution of Earnings}

The Colony Capital institutional investor strategy appears to be clear: receive significant revenue from the investment in Accor capital and limit risk by entering into an alliance with the investment fund Eurazeo. Accor is led to sell assets, which allows the Group to give special dividends each year, in addition to higher dividends than those paid during the 
previous years ${ }^{17}$. This redistribute behaviour appears to be the same one that financialized U.S. companies have used since the 1990s (Lazonick \& O'Sullivan, 2000).

\section{Socially 'Irresponsible' Restructurings}

Restructurings' downsize strategy, as highlighted by Lazonick and O'Sullivan (2000), had not been socially responsible before the 2005 Accor financialization. Indeed, these changes were not announced to the employees and to their representatives (French trade unionists, interviews of November 2008 and January 2009, IUF official, interview of September 2009). The employees, who worked in hotels that were put on franchise or management contracts or whose buildings were sold, would leave the circle of the Accor Group and change employer. These changes occurred little by little, and with the utmost discretion, especially if there was no labour representation in place (French trade unionists, interviews of November 2008 and January 2009, IUF official, interview of September 2009). By definition, these 'silent practices' (Beaujolin \& Schmidt, 2008, p. 8), cannot be anticipated. They end up with employee reductions that are not made clear in the documents created by management (annual reports, reference reports). It is no longer a question of employability (once the change has occurred, Accor is no longer responsible for any reclassification deemed necessary by any job cuts carried out by the new employer) or of personal and skill development.

\section{Strategic Restructurings and Network Organization}

Since 2005, restructurings have occurred as part of a previously implemented logic (selling to increase stockholder value) but their size marks a rupture and the separation of the group into two activities corresponds to a radical reorientation. These restructurings appear to be the result of a strategic approach (Pichault \& Rorive, 2007) and they stress the Accor business network model. This hybrid scheme is particularly complex as Accor has various and differing contractual links with its 'partners'. Due to its franchises, Accor is considered an integrated network; due to management contracts, it is a pendulum network with Accor executives managing hotels that Accor does not own. Finally, due to stable relationships with real estate investors and with other providers, Accor is a federated group.

\section{HRM Decentralization and Segmentation and Job Cuts}

We can expect that the effect of this on HRM is the same as observed by Pichault and Rorive (2007) in the three types of networks. Personnel management is given over to local administration. Decentralization is particularly strong as one hotel can actually employ less than five people. Segmentation is also much elaborated and the group will only employ highly qualified employees who can provide a high value service. The step-by-step low-skilled employee outsourcing (cleaning, reception) is indeed not only a negative signal to all employees and their representatives but also could be argued to put at risk the quality of services offered to clients and, with this, potentially compromises the future of the hotel business. The recent and important Accor downsizing has not been announced in corporate communication.

\section{Media-Oriented Management}

According to the authors, the Accor management of human resources is oriented towards a media approach. An employee representative underlined that the group signed exhibitionagreements that are quoted in corporate communication but are not really implemented. National agreements are used for external purposes (the diversity agreement signed in 2007 
was much discussed in the press) and as internal marketing signals. Thus, the subcontracting agreement signed in 2002 was seen by unions as top management's commitment to reduce cleaning outsourcing. The outsourcing policy with franchises and management contracts considerably narrowed the scope of this agreement ${ }^{18}$. Finally, the Group signed the second IFA in 1995 (which is highlighted in the group reference reports), but the IUF proposal to revise this agreement to reinforce Accor engagements in favour of trade union rights was rejected by the management team (Barreau \& Arnal, 2010).

The media scheme is present at each level of management in the group. We have quoted the euphemisms used to describe the operating strategy that gradually deprived the group of its real estate, as well as the one that masks downsizing. Strategic decisions are themselves signals to investors (Allouche \& Garaudel, 2007). Thus, the announcement of the Group's activities split also shows the need for better communication with investors (2009 reference report, p. 22), who can then measure each activity's profitability, getting the maximum expected return on their investment in prepaid services. This choice is very risky for the hotel business which, having a lower profitability than prepaid services, could potentially be dismantled and resold to several competitors.

\section{Shareholder versus Stakeholder-Oriented Models}

Using the Accor example, in the authors' opinion, it is clear that a group, whose principal shareholder is an investment fund, has as its primary objective: the creation of maximum profitability and share value. This requirement leads to poor treatment of all the stakeholders involved (other than the shareholders), in particular, its employees and clients. The corporate governance based on the principle of maximizing shareholder value has recently resulted in tragic effects on U.S. economy. In this governance model, the principal shareholders (i.e. institutional investors) do not know anything about the firm, its core activity and its market. They are exclusively interested in share liquidity and profitability. They do not guide the firm strategic choices towards middle- and long-term development. The behaviour of these shareholders jeopardizes firm survival. The expansion of this model to Europe and other continents places global economy under a financially instable system (Aglietta \& Rebérioux, 2004). Firms responded to pressures in order to take into account the interests of other stakeholders by elaborating sustainable development and CSR policies. But in many cases (as suggested above with Accor case), these policies are essentially media oriented. Consequently, voices emerge to restore the balance of power inside firms and to 'democratize' firms. To give a real decision power to employees (stakeholders whose interests are greatly endangered by corporate financialization) is now a necessity. Beyond an already granted European information and consultation right, specifically in case of restructuring, employees' participation to boards of directors or to supervisory boards is one of the proposed solutions. It is already implemented in some European countries (Germany, Sweden).

\section{CONCLUSION}

Conforming to the expectations discussed in management literature, the Accor Group is a classic textbook case in the way that its financialization has led to practically immediate and dramatic upheavals resulting in the fragmentation of the group in 5 years. Further research might consist of analysing other examples of financialization in French and European groups in order to compare these results. However, in a context where financialization is accented, the efforts of national and European authorities to render restructurings socially responsible risk to be in vain. Employees will still be threatened with job cuts, lays off and firm 
bankruptcies. A new governance model, which provides the employees with a real decision power, is necessary to avoid future financial crisis.

\section{NOTES}

1. Corporate social responsibility.

2. European Metalworkers' Federation.

3. Essentially, we are studying top management's respect for social commitments since, in the case of restructuring, it is the social issues (job cuts, layoffs, damaged work conditions) that are the most crucial. Environmental commitments are not as much in question.

4. Institutional investors (including American pension funds) are now part of many French companies share capital (Morin \& Rigamonti, 2002).

5. International Union of Food, Agricultural, Hotel, Restaurant, Catering, Tobacco and Allied Workers' Association. IUF is one of the 10 Global Union Federations.

6. In this chapter, we have used only a part of the collected data: documents produced by Accor Group management (available on Accor website) and interviews of French trade unionists (November 2008, January and March 2009) and of an IUF official (September 2009).

7. 'An IFA may be defined as an international agreement concluded by a multinational company and an international trade union organization. This is one of the results of a transnational social dialogue between social partners' (Daugareilh, 2006, p. 117).

7. European directive concerning the institution of a European Works Council or a procedure of information and consultation of workers in European firms and groups, JOCE no. L254 of September 30, 1994.

9. 'Protocole sur l'orientation des conditions de recours à des entreprises extérieures de nettoyage' signed on 3 December 2002.

10. Agence des Marchés Financiers, French independent agency in charge of financial markets.

11. Underlined by us.

12. Underlined by us.

13. In 1982 Jacques Borel International was the European leader in catering and the restaurant ticketing world leader.

14. Underlined by us.

15. Underlined by us.

16. One Accor manager is sometimes in charge of two or three hotels.

17. The dividend per share paid in 2003 is about 1.05 (2004 reference report), in 2007 it is 1.65 to which the 1.50 special dividend is added (2008 reference report). Thus, the 2007 dividend per share is three times higher than that of 2003.

18. This scope is anyway limited to French territory, despite EWC members repeated requests to extend the agreement scope to European level.

\section{REFERENCES}

Accor reference reports. (1997-2009). January 2008 and June 2010 files browsing. Retrieved from: http://www.accor.com/fr/finance/communiques-et-documentation/rapport-annuel-et-documents-de-reference.html Accor annual report. (2007). January 2008 file browsing. Retrieved from:

http://www.accor.com/fr/finance/communiques-et-documentation/rapport-annuel-et-documents-de-reference.html Accor institutional brochure. (2009). June 2010 file browsing. Retrieved from: http://www.accor.com/fr/finance/communiques-et-documentation/rapport-annuel-et-documents-de-reference.html Accor press release. (2009).May 13, June 2010 file browsing Retrieved from:

http://www.accor.com/fr/finance/communiques-et-documentation/rapport-annuel-et-documents-de-reference.html Aglietta, M., \& Rebérioux, A. (2004). Dérives du capitalisme financier. Paris: Albin Michel. 
Allouche, J., \& Garaudel, P. (2007). «Les restructurations comme prolongement de tendances courttermistes ». In: J. Allouche \& J. Freiche (Eds.), Restructurations: regards croisés (pp. 199-214). Paris: Vuibert.

Barreau, J., \& Arnal, J. (2010). Responsabilité sociale de l'entreprise, comité d'entreprise européen et négociation collective transnationale: l'exemple du groupe Accor. Négociations, 2010/2, automnehiver, 21-35.

Beaujolin, R., \& Schmidt, G. (Eds.). (2008). Restructurations d'entreprises. Des recherches pour l'action. Paris: Vuibert.

Béthoux, E. (2008). «Le comité d'entreprise européen: un acteur de la responsabilité sociale de l'entreprise? », Revue de l'IRES, 57, 87-110.

Caire, G. (2004). «Une évaluation critique de la politique de développement durable du groupe Accor ». In: C. Offredi (Ed.), La dynamique de l'évaluation face au développement durable. Paris: L'Harmattan.

Conway, N., Decker, S., Konzolmann, S., Petit, H., Rebérioux, A., \& Wilkinson, F. (2008). "The influence of stock market listing on human resource management: Evidence for France and Britain". British Journal of Industrial Relations, December, 631-673.

Daugareilh, I. (2006). "Les accords-cadres internationaux: une réponse européenne à la mondialisation de l'économie ?» In I. Descolonges \& B. Saincy (Ed.), Les nouveaux enjeux de la négociation sociale internationale (pp. 116-135). Paris: La Découverte, coll. "Entreprise et société ". Fayolle, J. (2006). Responsabilité sociale des entreprises, restructurations et délocalisations. Document de travail IRES, $\mathrm{n}^{\circ} 06.01$.

Lazonick, W., \& O'Sullivan, M. (2000). "Maximizing shareholder value: A new ideology for corporate governance". Economy and Society, 29, 13-35.

Le Figaro, 11 December 2009

Le Monde, 16 December 2009

Montagne, S., \& Sauviat, C. (2001). «L'influence des marchés financiers sur les politiques sociales des entreprises: le cas français ». Travail et emploi, $\mathrm{n}^{\circ}$ 87, juillet, 111-126.

Moreau, M. A., Negrelli, S., \& Pochet, P. (dir). (2009). Building anticipation of restructuring in Europe, Bruxelles, Bern, Berlin, Frankfurt am Main, New York, Oxford, Wien.

Morin, F., \& Rigamonti, E. (2002). Evolution et structure de l'actionnariat en France. Revue française de gestion, 14 1(nov-déc), 152-182.

Noël, F. (2007). «De la responsabilité légale à la responsabilité sociale: la quête de légitimité des dirigeants ». In: J. Allouche \& J. Freiche (Eds.), Restructurations: Regards croisés (pp. 301-320). Paris: Vuibert.

Pichault, F., \& Rorive, B. (2007). «Les restructurations et les nouveaux périmètres organisationnels: le rôle de la fonction RH ». In: J. Allouche \& J. Freiche (Eds.), Restructurations: Regards croisés (pp. 199-214). Paris: Vuibert.

Ray, J. E. (2006). «Pour des restructurations socialement responsables ». Droit social, March, 249259.

Wahab, A.\& Pilgram, J. J. (1997). Tourism, development and growth: The challenge of sustainability. London: Routledge.

Wills, J. (2002). "Bargaining for the space to organize in the global economy: A review of the ACCOR-IUF Trade Union Rights Agreement". Review of International Political Economy, 9(4), 102119.

Yin, R. K. (2009). Case study research: Design and methods (4th ed). London: Sage. 